\title{
Average Male Live Fetal Weight
}

National Cancer Institute

\section{Source}

National Cancer Institute. Average Male Live Fetal Weight. NCI Thesaurus. Code

C124629.

A measurement of the average weight of all live male fetuses. 